\title{
Habonaron do Bona as the Local Wisdom of the Simalungunese Community of North Sumatera in Preventing Corruption
}

\author{
Sri Sulistyawati ${ }^{1}$, Susy Deliani ${ }^{2}$, and NelvitiaPurba ${ }^{3}$ \\ \{1srilistya@umnaw.ac.id\} \\ 12 Muslim Nusantara (UMN) Al Washliyah University
}

\begin{abstract}
Corruption criminal act is considered as an extraordinary crime. Combating and eradicating it will not be significantly successful if it is carried out only by law enforcement, bureaucracy, and KPK (Corruption Eradication Committee); people, especially families also play their important role in preventing anyone from committing corruption criminal act through local cultural wisdom because it has been instilled since one is born. The concept of noble values of the Simalungunese belief in Habonaron do Bona contain the doctrines of Divinity, man, nature, and tenets which organize the relationship between man and God, man and man, and man and nature. ${ }^{1}$ This concept has its own philosophy of the truth which becomes the guideline and guidance for life which says, "Every Simalungunese is required to adhere to God's order which is actualized by carrying out his religious duties well and correctly. It also teaches him how to be credible in his spirit, mentality, and behavior, to take responsibility, to never give up, to be ready to sacrifice for his country and his fellowman, to work hard, to be tough, to persevere, to be fond of doing social activity, to get ready to help solve other people's problems, and to be law abiding. The research used Research and Development method with descriptive sociological approach on local wisdom in Habonaron do Bona concerning preventing the Simalungunese community from committing corruption criminal act. The result of the field research showed that Habonaron do Bona had not yet been implemented by the Simangulunese community which could be proved from numerous corruption criminal acts committed by their authorities.
\end{abstract}

Keywords: Local Wisdom, Habonaron do Bona, Preventing Corruption

\section{Introduction}

Corruption in Indonesia runs rampant and has penetrated all walks of life. It is increasing each year, and has caused the State's big financial loss since it is done systematically; therefore, Indonesia gets bad image in throughout the world which makes Indonesian people feel inferior and loses self-confidence. Consequently, many investors shift their capital 
investment to the other neighboring countries. This condition also occurs in North Sumatera where two of its governors, the Mayor, Regent, and the members of its Parliament committed corruption criminal acts. It also occurs in Simalungun Regency which triggers the public figures and the adat leaders to remind the Simalungunese of the philosophy of Habonaron do Bona and to hold and practice it in their daily life to avoid committing criminal act.

Unfortunately, many Simalungunese children do not know the concept of local wisdom in Habonaron Do Bona although it can be practiced in their daily life in order to prevent from illegal acts and norms, especially from corruption.

Every region in Indonesia has a Local wisdom which has some values of Character in their society. In Lombok Sasak, Aji Krama as a tradition of Marriage has a strong philosophical foundation, has 100 category to understand The Nature Of Allah SWT. It contains local Wisdom Value of Characters and it is represented in the form of religious Character [1]

In Bali Local wisdom value are relieved to character education for first grade primary school. Local Wisdom Values in Balinese Folktales are: Compassion (Karuna), Tri Hita Karuna, Tri Parartha, Alertness, Kharna Phala, Politness. Tri Dandim, Mitia Hardaya. That are relevant to character Education for students [2] Local wisdom represent Character value and instrument for Internalization of public services Innovation can be adopted in the company as public Service Innovation: Local wisdom as a value of public services. Innovating, Local value as Instrument to design service Innovation, will be a model of sustainable inclusive and contextual innovation based on culture [3]Local wisdom found in Sayu Wiwit Folklore as a mean for Revitalizing behavior, the story of Sayu Wiwit considered as a historical story that can be verified with historical evidence such as Confidence, Creativity and behavior that suggested not giving up.[4]MinangKabau Local wisdom as basic character to shaping character or personality value system of community or society with the basic aspect of Implementing educational Characters[5]

In Passanggrahan district, kampung Kahuripan, Education is based on Local Wisdom in: Keeping Conservation, Deliberating to agree, Cooperation, Politeness, Modesty. The process of internalizing is through teaching, familiarity, modeling, motivating and low enforcement [6]In Cirebon city, the kinship system which is one of the Local Wisdom based on Characters Education Childhood Education in PAUD : Character Education can be integrated into every subject and link to the context of every day life [7]. Can Local Cultural Wisdom of Habonaron do Bona with its moral values prevent the Simalungunese from committing corruption criminal act in this era?

\section{Research Method}

The research used Research and Development method with descriptive sociological approach about local cultural wisdom of Habonaron Do Bona in preventing people from committing corruption criminal act. The research used Rural Development, descriptive normative and sociological methods on Local Wisdom Culture, Habonaran do Bona related to the way to prevent the people from committing corruption criminal act. The data were gathered by conducting interviews with public figure and young people and direct observation in the field. 


\section{Results And Discussion}

As the time passes, the Simalungunese public figures begin to think about re-actualizing the life philosophy of Habonaron do Bona which has its basis on truth. According to the adat leaders, this philosophy is applied to the national leadership so that it is developed by Partuba Maujana Simalungun (PMS), Medan as the philosophy of life for the Simalungunese so that a forum of discussion involving academicians processed, dug up, formulated, and actualized Habonaron do Bona in the $21^{\text {st }}$ Century on August 12, 2017 [8]

The noble values in Habonaron do Bona contain the principles of Deity, man, nature, and the relationship between man and God, man and man, and man and nature. ${ }^{2}$ In this philosophy, God Almighty was the beginning of things. He us called Naibata, (one) and the NamarHuasa (the Almighty) so that the world and its whole content is His creation. Naibata becomes the Guidance, the Keeper, and the Savior. ${ }^{3}$ Indigenous people pay homage to their ancestors that are called Simagot, Begu Jabu, Tua-TuaatauBitara Guru who become the connectors with God the Almighty who gives His blessing to all persons who are sincere, to the spirits of the ancestors, and to holy places. His power has made Him have many names such as Namar Huasa (God the Almighty), Namam Botoh or Ne Pentar (the Omniscient), Pernolong (the AllMerciful), Pangarak-arak (the Guidance), Bona Habonaron (the Source of Truth), etc.

According to Habonaron do Bona, Human Beings were created in man and woman (daboru-naboru) who have soul. Death is the separation between the body and the soul, and the soul will live forever with God in a certain place. Man in tondi and when he dies he is called sumagot.

According to Habonaron do Bona, nature is God's creation. It has its own power which comes from God and from the ancestors' spirits so that halonglongan (flood), sohul-sohul (earthquake), aliogodoras (storm), porhas (lightning), harvest failure, epidemic, and no offspring are God's and the ancestors' will. Man has his obligation toward God, fellowmen, and nature since he is created by God. Therefore, the people of Habonaron do Bona have to always remember and worship Him, especially in bittang baggal (full moon). Thy also have to visit the ancestors' shrines (manembah Suamgot). These activities are closely related to ceremonies:

1. Dauh hidup ceremony;

2. Removing Carcass ceremony;

3. Pesta Tuan (Robu-robu/Harja Tuan) ceremony which is held to pray to God and the ancestors in starting a business or planting rice in order to get good result;

4. Entering a new house ceremony;

5. Paying homage to ancestors' spirits as the village protectors (mamberetambunan/pagar parsakutuan);

6. The ceremony of paying homage to the sacred Spirits as the village guards.

7. The ceremony of paying homage to the Protector of Sacred Places (mamberesimumbah). 
Besides his obligation toward God, man also has to have credibility, sense of shame, and self-acknowledgment. Man's obligation toward his fellowmen is found in the form of orders and prohibitions. If these orders and prohibition are obeyed, there will be a peaceful community. The orders ads prohibitions are as follows:

1. Respecting parents and other people with full of politeness(hamathubaniurangtuaoppa hasomanmarihutkonturur);

2. Respecting teachers (hormathubani guru/hormathubanisibere ajar);

3. Helping other people (manappati);

4. Prohibiting to kill other people, including abortion;

5. Prohibiting to get married with the same clan (ulangmarboto-boto);

6. Prohibiting to make other people shed their tears until "they get yellow" (ulangiabenmanetek iluhnihalakmagorsing);

7. Prohibiting to beg (be a beggar) (ulangtedek-tedek);

8. Prohibiting to make other people in trouble (ulangmanusahi);

9. Prohibiting to tell a lie (ulangmarguak);

10. Prohibiting to use abusive language to other people (ulangmanurai);

11. Prohibiting to be a moneylender (ulangmakhilang);

12. Prohibiting to deceive and to slander other people (ulangmagotootoi/ ulangmangkhianat).

Man's duty and obligation, according to the teaching of Habonaron do Bona are that man is prohibited to kill plants and animals randomly because it can damage nature (ulangmassedai). Nature has to be conversed since it gives great benefits to human life. Appreciation and request to God concerning nature is realized by conducting some ceremonies in agriculture in order that nature will be friendly with human beings and produce abundant crop. Some of the ceremonies are

1. Robubuangboro (praying so that the rice plants are not attacked by pests);

2. Membereeme (praying during swelling rice grains);

3. Memutik (praying while rice plants become yellow).

4. Menutuppanjang (praying while rice plants have been piled up on a certain place);

5. Menutuphobon(praying when the harvesting time will come).

It seems that the teaching of Habonaron do Bona has the values which are able to establish one's personality which has noble values[9]

The 5 (five) points of teaching contained in Habonaron do Bona pointed out by David E. Purba are as follows: :

1. Oppu-Oppu;

2. Didihil;

3. Dangsina;

4. Tutuduh;

5. Tutualang.

Ad.1. Oppu-Oppu (Marguru Na Bonar), Marguru Na Bonar means "Be a student of Trustworthiness," the truth to honor; learn from a brightened person. This saying has complicated meaning since many things which can be a "teacher": nature, animals, plants, fellowmen, other people's experience, Holy Books, teachers in formal education, religious teachers, teachers in non-formal education, and anyone who has intelligence and prowess. All of them can be used as teachers since the students can get knowledge, benefits, comparison, guidance, life exemplary, warning, etc., so that they can have self-correction and self-renewal. Ad.2 Didihil (Maruhur Na Bonar), Marunur Na Bonar means "to think accurately" and to have accurate perception because the word, maruhur does not only mean "to daydream" but it also means to think correctly since there is a sense of intelligence in it. 
Ad.3 Dangsina (Marhata Na Bonar), Marhata Na Bonar means that we should not ignore ethics when we talk to someone because without ethics there will be problems. Marhata Na Bonar occurs when we have Marguru Na Bonar (learned from the right man) since utterance expresses paruhuran $\mathrm{Na}$ Bonar budhi and expresses accurate intellectuality and intelligence. Its indication is that when we want to talk, our conscience works and our intelligence will guide us. This is the characteristic of a person who has Marguru Na Bonar.

Ad.4 Tutuduh (Marhoja Na Bonar).Work and act accurately. As it is mentioned above, we should speak and act accurately since they are the expression of our "consciousness." We express something what he have in our mind, whether it is through speech or action. The proof which shows that we have learned from the right person (margurunabonar) and speak accurately (maruhurnabonar), we will work or act accurately (marhojanabonar), and we will eventually know which speech is not accurate and which action is not right.

Ad.5. Tutualang (Marsaor Na Bonar) Marsaor Na Bonar means socializing accurately. There is the suggestion from elderly people ("Pertuha") which says, "Socialize with wise people and with right people so that you do not get bad luck. What it means by good socialization is how far we can protect ourselves against bad environment such as among our friends who are addicted to narcotics. How strong we are in maintaining our good sense when we are among those who like to tell lies, who are hypocrite, who are egoistic and bigot since sooner or later we will be influenced by our environment. Therefore, we have to fortify ourselves by socializing with correct persons. Marsaornabonar means socializing accurately which is identified by good environment so that we will sharpen (enriching to each other), love (teaching to each other), and rear (loving to each other) for the sake of man himself. If we do not have these three things in our mind or in our group, we will get "sickness" such as arrogance, narrow-mindedness, racism, conflict, hypocrisy, etc.

Nevertheless, from the data found in the field, there are still many Simalungunese authorities who are involved in committing corruption criminal acts. This shows that the value of Habonaron do Bona is only considered as a philosophy without being implemented in their daily activities. The result of interviews with some respondents showed that corruption was highly influenced by social environment. This was in accordance with the Theory of Social Solidarity pointed out and developed by Emile Durkheim (1858-1917). This theory states that man is passive, and he is controlled by his own community. Thos Social Solidarity is actually an abstract unit. Durkheim points out that an individual is morally neutral and his community that creates his personality. He also controlled individuals through a social fact he had studied through education and environment. Since man is passive, his community that controls $\operatorname{him}[10]$

From the theory proposed by Emile Durkheim, it was found that a community has greater influence on establishing a person's behavior than his environment. A society that has corrupting cultural and institutional system will automatically establish corrupting individuals even though they are religious and pious [11] This theory is strengthened by the theory of GONE (Greed, Opportunities, Needs, and Exposure). This theory was developed by Jack Bologne which was known as GONE theory which states that any fraud and corruption are mainly caused by greed, opportunity, need, and exposure. A corruptor is greed; he never feels satisfied with what he has. Opportunity is a system which provides an opportunity to commit corruption, not only in individuals, but also in an organization or a society that give the opportunity to do fraud. Need is a mental behavior; it is about a person who never feels satisfied and always needs something more and more. Exposure is punishment for corruptors which does not provide deterrent effect for them and for other people [12] 


\section{Conclusion}

Habonoron do Bona as the Simalungunese philosophy of life contains honorable values which have to be instilled in their daily life. It was created by their ancestors for the Simalungunese community to fortify them from illegal acts and legal norms in the community.

In reality, however, in this global era, the values of Habonaron Do Bona values begin to fade since there are many authorities who have been mandated by the Simalungunese commit corruption criminal act. It is recommended that the philosophy of Habonaron Do Bona be used as the philosophy of life and promoted through formal and non-formal education, families, and non-government organizations so that it can be used as a barricade for the Simalungunese community to avoid them against committing illegal acts.

\section{References}

[1] A. Agusman, I. Suyitno, and Y. Pratiwi, "Local Wisdom And Value Of Character In Level Of Aji Krama At Sasak Wedding Tradition," ISLLAC J. Intensive Stud. Lang. Lit. Art, Cult., 2018.

[2] R. Relin, R. I. W., and B. W. S, "Local Wisdom Values in Balinese Folktales That Are Relevant to Character Education for the First Grade at Primary School," J. Lang. Teach. Res., 2018.

[3] T. Savira,E.M and Krismiyati, "Involment of Local Wisdom As a Value and an Instrument Of Internalizing of Public Service \& Organization International," J. Adm., vol. 24, pp. 1-13, 2017.

[4] F. N. Fatimah, E. T. Sulistyo, and K. Saddhono, "Local Wisdom Values in Sayu Wiwit Folklore as The Revitalization of Behavioral Education," KARSA J. Soc. Islam. Cult., 2017.

[5] N. Taher, "Local Wisdom: The Values System of Minangkabau Ethnic Customs as a Fundamental Basic of Educational Character in Indonesia," Kolok. J. Pendidik. Luar Sekol., 2018.

[6] Helmi Aziz, "Internalization Of Character Education Based On Local Wisdom (Field Studies in Kampung Kahuripan / Tajur Pasanggrahan Village of Purwakarta Regency)," Pendidik. Islam, vol. 5, no. 1, pp. 85-100, 2016.

[7] T. J. Ernawati T, Rasdi E.S, Wahyu H, "Local-Wisdom-Based Character Education Management in Early Childhood Education," J. Educ. Dev., pp. 348-355, 2018.

[8] N. Sulistyawati, S., Risnawaty, Model Pendidikan Anti Korupsi Pada Siswa Berbasis Nilai Karakter Bangsa. Medan, 2016.

[9] Anonim, "Makna Filosofi Habonoran do bona," 2019. [Online]. Available: https://www.hetanews.com/article/105909/makna-filosofi-habonaron-do-bona-bagi-masyarakatsuku-simalungun. [Accessed: 27-Sep-2019].

[10] E. Handoyo, Pendidikan Anti Korupsi. sEMARANG, 2009.

[11] A. Nader, Kepemimpinan Berdasarkan Kecerdasan Spritual. Jakarta, 2002.

[12] K. Sunarto, Pengantar Sosiologi. Jakarta, 2004. 